\title{
Usufruto de acções, de partes e de quotas sociais
}

\section{Barbosa de Magalhães}

Professor da Faculdade de Direito da Universidade de Lisboa. Da Academia das Ciências de Lisboa.

Ao prezado Amigo e eminente Colega Professor Dr. Waldemar Ferreira.

1 Dentre os variados problemas, a que a figura do usufruto dá lugar, avultam, pela sua importância e pela maior frequência com que ùltimamente têm surgido, os que respeitam às acções, partes ou quotas sociais (1).

São problemas complexos, porque a sua solução depende, não apenas do sistema e das disposições legais relativas ao usufruto, como também do sistema e das disposições legais relativas às várias espécies de sociedades - por acções, em nome colectivo e por quotas.

Geralmente, os que têm preocupado os legisladores e os tratadistas são os que se referem ao usufruto de acções e de quotas; mas certo é que, embora mais restritamente, por força da lei, e menos frequentemente, por força das circunstâncias, podem as partes sociais ser objeto de usufruto.

Dizemos mais restritamente, por força da lei, referindonos às disposições que, como a do art. 161 do Cód. Com. português (2) fazem depender a cessão das partes sociais do consentimento de todos os sócios.

1. Quem ainda tiver dúvidas sobre a possibilidade do usufruto de acções pode ver o problema tratado com desenvolvimento por SANCHEZ TORRes em. Usufruto de acciones de sociedades mercantiles, (Madrid, 1946), pág. 11 e seg.

2. Todas as vezes que citamos disposições de Códigos ou de outros diplomas legais sem indicação dos países a que respeitam, queremos referir-nos aos portugueses. 
Esta disposição atendendo à sua redação genérica e o fim, que a ditou, é aplicável à constituição do usufruto de uma parte social quer por contrato oneroso ou gratuito, quer por disposição testamentária.

Mas, dado o consentimento nela exigido, pode o usufruto constituir-se; e pode ainda, por fôrça da lei, ser constituido sobre uma parte social.

Sem falar no caso do usufruto dos pais sobre os bens dos filhos menores (Cód. ICiv., art. 145), aos quais podem caber, por sucessão legítima, partes sociais, pode dar-se este caso: - se o sócio, sendo casado, falecer sem deixar ascendentes, nem descendentes, e tiver irmãos ou sobrinhos, fica, por força da lei (Cód. Civ., art. 2003 §ún.), o cônjuge sobrevivo usufrutuário dos beris da herança; e se entre os bens, que a constituem, existir uma parte numa socicdade em nome colectivo, o cônjuge fica tendo o usufruto dessa parte social.

Isto, porém, raramente poderá acontecer, por isso que, salvo estipulação em contrário, as sociedades em nome colectivo dissolvem-se pela morte de qualquer dos sócios (Cód. Com., art. 120, §§ $10^{\circ}$ e 5..$^{\circ}$ ).

Neste caso, a disposição legal é pouco conforme com a natureza especial destas sociedades - intuitus personae -, mas certo é que, se por fôrça do pacto social a sociedade se não dissolve pela morte do sócio, a lei tem de se aplicar.

Foi atendendo a essa natureza especial das sociedades em nome colectivo que, como temos sustentado (3) e já se tem julgado (4), o conjuge do sócio de uma sociedade em

3. Gazeta da Relação de Lisboa, t. 33, pág. 171.

4. Acórdão da Rel. de Lisboa de 24 de Março de 1917 e do Supremo Tribunal de Justiça de 29 de Maio de 1917, ma cit. Gaz., t. 33, pág. 170 e 171.

O Ac. da Rel. de Lisboa de 19 de 1938 (na cit. Gaz., t, 51, pág. 315) julgou, com o nosso aplauso, que, em inventário consequente a 
nome colectivo não é sócio, embora a parte social seja comum de ambos os cônjuges, mas, neste caso de comunhão, pode ela considerar-se limitada pela natureza especial das referidas sociedades pelas normas legais que as regulan, e, no caso de usufruto, essa limitação não é possível.

Mas não será sócio todo e qualquer usufrutuário duma quota social?

Este problema, que se afigura fundamental, não se põe apenas quanto ao usufruto de partes sociais, mas também ao de acções e de quotas.

2 Antes de o discutirmos, observemos que, se os problemas relativos ao usufruto de acções, partes sociais e quotas têm o seu aspecto geral e se para a sua solução há que atender a princípios gerais de direito e a considerações de ordem doutrinal, certo é que a solução de uns e outros depende essencialmente das normas legais reguladoras quer do usufruto, quer das sociedades comerciais.

O que também é certo é que, geralmente, essas disposições são deficientes e há então que suprir as lacunas da lei.

E um problema geral surge aqui: - podem os interessados, nos respectivos pactos sociais, regular a seu arbítrio o usufruto das acções, partes sociais, ou quotas, determinando por exemplo, qual dos dois, nu-proprietário ou usufrutuário, é sócio, ou se o são ambos, qual deles pode intervir nas assembléias gerais, qual deles tem o direito de preferência no caso de emissão de novas acções, etc.?

Se o problema é geral, a sua solução não pode ter um carácter de generalidade, pois, como é fácil de ver, depende das disposições imperativas da lei sobre o usufruto e sobre o exercício dos direitos sociais.

divórcio, não é admissível licitação pela ex-cônjuge mulher na quota que o marido tem numa sociedade por quotas e que lhe deve ser encabeçada, desde que no pacto social se estipulou que as quotas não podem ser transmitidas sem consentimento da sociedade, que tem. o direito de opção. 
Não procuramos, pois, dar-lhe solução aqui, dizendo apenas que há que respeitar o princípio da autonomia da vontade em tanto quanto o permitam os princípios gerais de direito, a natureza do contracto-instituição, que é a sociedade, e as normas legais reguladoras das diversas espécies de sociedades.

Pode considerar-se raro o caso de o pacto social regular num ou noutro ponto o usufruto de acções, partes sociais e quotas (5). No entanto é natural que, a prouco e pouco, se vá tornando mais frequente.

Quanto às legislações, se algumas, como a brasileira, a suiça e a italiana, contêm normas, em que se procura solucionar um ou outro problema, outras há que são absolutamente omissas.

$\mathrm{Na}$ legislação portuguesa, o Cód. Com. e a lei das sociedades por quotas de 11 de Abril de 1901 guardaram silêncio sobre o assunto, mas o velho Cód. Civ., no seu art. 2237, dispõe, quanto ao usufruto de acções de companhias, que o usufrutuário não pode levantar o respectivo capital senão para o inverter nos dois casos mencionados e com o consentimento do proprietário, ou seu suprimento judicial.

3. O usufrutuário de uma acção, de uma parte social, ou de uma quota é sócio?

Geralmente o problema não é resolvido pelas legislações, nem é posto nem discutido pelos Autores; apenas uma ou outra legislação o resolve (6), e um ou outro

5. Nos estatutos da sociedade portuguesa Empresa de Navegação Mercante vê-se esta disposição: — "Art. 30 - Cada acionista, membro da assembleia geral, terá um voto por cada grupo de 25 acções até ao limite legal. - $\S$ ún. - Os acionistas, que forem meros usufrutuários só terão direito a votar nas assembleias ordinárias; nas assembleias extraordinárias competirá o voto aos proprietários dessas acções".

6. Cod. Civ. ital. de 1942, art. 2352. Dec.-lei brasileiro n. ${ }^{\circ} 2672$, de 26 de Setembro de 1940 , art. $111 \S 4 .^{\circ}$, um e outro considerando sócio apenas o nu-proprietário. 
tratadista se the refere (7); mas em Portugal já dele se ocuparam a jurisprudência e a doutrina.

Decidiu que o usufrutuário não é sócio o Acórdão da Relação de Lisboa de 18 de Abril de 1890 (8) e com esta decisão concordou o Prof. José Tavares (9).

Mais recentemente assim decidiu também o Ac. do Supremo Tribunal de Justiça de 14 de Maio de 1947 (10), mas da decisão discordou o Prof. Anselmo de Castro (11).

Aquele $1^{\circ}$. Ac. recaíu sobre o seguinte problema: tendo uma sociedade realizado uma nova emissão de acções e, dando os respectivos estatutos o direit de preferência aos accionistas, esse direito cabe ao nu-proprietário ou ao usufrutuário?

O Ac. decidiu que cabe ao proprietário, aduzindo os seguintes argumentos: a) a preferência é dada aos accionistas, mas os usufrutuários não o são, porque só o proprietário prode dispor das acções; porque de alguns arts. dos estatutos se vê que é assim; e porque não é a posse, mas sim a propriedade, que confere a qualidade de accionista; b) foi o proprietário que desembolsou o capital, ou o adquiriu por transmissão e, porisso, a preferência cabe a ele e não ao usufrutuário, que tem apenas um direito temporário e eventual ao dividendo.

José Tavares entende que o usufrutuário não é sócio e não pode, por isso, exercer os direitos de sócio proprietário. Mas entende também que este principio geral sofre as restrições necessàriamente resultantes dos direitos aos dividendos de lucros, que lhe pertencem nos termos dos arts. 2202 e 2205 do Cód. Civ.

(7) SANchez Torres, ob. cit., pág. 72, que considera sócios o nu-proprietário e o usufrutuário, e Ezcurdia (artigo publicado na Guipuzcoa Económica, de Maio de 1946, citado por SANchez TorRes, ob. cit., pág. 186), que considera sócio apenas o nu-proprietário.

(8) No Direito, t. 23, pág. 398.

(9) Sociedades e empresas comerciais, 2a. ed., pág. 545.

(10) Boletim Oficial do Ministério da Justiça, t. 7º, pág. 184.

(11) Revista de Direito e de Estudos Sociois, t. $3^{\circ}$., pág. 66. 
$02^{\circ}$. Ac., que decidiu que o usufrutuário de uma quotæ não pode requerer a dissolução da sociedade, não aduz pròpriamente argumentos, faz apenas afirmações: - is simples usufrutuário não pode legalmente considerar-se sócio; sócios são apenas os donos das quotas sociais; o usufrutuário é apenas dono dos rendimentos, que a quota produzir; não tem a propriedade de qualquer parte do capital social; dos termos dos arts. 2188 e 2189 do Cód. Civ. apenas se pode concluir que o usufrutuário dos rendimentos duma quota social goza da propriedade plena sobre esses rendimentos e nada mais; não é proprietário da quota ou de parte dela; e, não o sendo, não é sócio; o direito de propriedade da quota não se dividiu por efeito de o usufruto dos seus rendimentos ficar pertencenda a outra pessoa; ficou apenas limitado; os direitos, que o art. 2206 do cit. Cód. confere ao usufrutuário, são apenas sobre os rendimentos, e não sobre a quota.

O Dr. Anselmo de CAStro limitou-se a dizer, contra a decisão do Ac., que ela peca por exagero na forma e na substância e que o usufrutuário é sócio, pois lhe caberrr todos os actos da gestão normal da sociedade, livremente, bem como a iniciativa dos actos, que excedem essa gestão quando tendam a evitar a perda do capital, actos que poderá praticar mediante procedimento judicial; e invoca a doutrina francesa que, em geral, só ao usufrutuário reconhece qualidade para tomar parte nas assembleias gerais ordinárias ou extraordinárias, inclusivamente quando visem a modificação dos estatutos.

Contra a tese dos Acs. podem invocar-se os preceitos dos arts. 2188, 2189, 2206, 2219 e outros do cit. Cód. segundo os quais, sendo o usufruto uma propriedade imperfeita, o usufrutuário goza, pelo que toca a essa fração, do direito de propriedade plenamente, salvas as restrições estabelecidas na lei, ou no título constitutivo da mesma propriedade; e ainda o usufrutuário tem o direito: - de per- 
ceber todos os frutos naturais, industriais e civis que a cousa produzir; "de gozar das cousas inerentes à cousa usufruida"; de gozar pessoalmente da cousa, emprestá-la. arrendá-la ou alugá-la e até alienar o seu usufruto; e de usar de todos os meios, que competem ao proprietário, para ser mantido no seu usufruto.

Os Acs. limitam os direitos do usufrutuário aos rendimentos, quando a lei lhe confere o gozo de todos os direitos inerentes à cousa usufruida e esta é a acção, a parte social, ou a quota, e não apenas os rendimentos expressão esta a que os Acs. nem sequer atribuiram um significado determinado.

O usufrutuário é tão sócio como o proprietário, pois que a acção, a parte social, ou a quota pertencem a ambos; - ambos são sócios, porque a um e outro competem alguns dos direitos e obrigações, que a lei confere e impõe aos sócios.

Adaptando ao caso a terminologia legal, pode dizer-se que ambos são proprietários imperfeitos.

Mas daqui resulta que não é pela circunstância de se considerarem ambos sócios, ou de se considerar sócio apenas o nu-proprietário, que podem solucionar-se os problemas relativos aos direitos e obrigações, que a um e outro - ao nu-proprietário e ao usufrutuário - competem.

O Cód. Civ. italiano de 1942, no seu art. 2352, atribuindo ao usufrutuário o direito de voto e o direito de opção, quando ele exista, pelo pacto social, na emissão de novas acções, dá a designação de sócio apenas ao nuproprietário.

Se, pois, se argumentasse dizendo que, porque o usufrutuário não é sócio, só tem os direitos que a lei expressamente lhe atribue, ele não teria, na Itália, direito ao dividendo!

Não é por ser sócio que o usufrutuário tem direitos e obrigações em relação à acção, parte social ou quota, que usufrue; é por ser usufrutuário. 
E bem de ver, pois, que não é nem de uma nem de outra dessas doutrinas que derivam elementos para a solução dos aludidos problemas; - que o princípio directivo e orientador no seu estudo e resolução não é o ser sócio apenas o nu-proprietário, ou o ser sócio também o usufrutuário.

4. nos princlípios gerais reguladores do usufruto que esse princípio se deve ir procurar.

E não é diffícil encontrá-lo — ao usufrutuário competem os direitos e obrigações que respeitam ao uso e fruição da coisa - da acção, da parte social ou da quota; - ao proprietário competem os direitos e obrigacões respeitantes à nua-propriedade da cousa.

$\mathrm{Na}$ aplicação deste princípio é que deverá ter-se em conta a natureza de cada uma das espécies de sociedades - por acções, em nome colectivo e por quotas - e ainda certas normas especiais reguladoras do usufruto, como seja a do art. 2.240 do Cód. Civ., segundo a qual o usufrutuário é obrigado a avisar o proprietário de qualquer facto de terceiro, de que tenha notícia e que possa lesar os direitos do proprietário; se o não fizer, responderá por perdas e danos.

Mas esta mesma norma pode sofrer restrições quando, por exemplo, se trate de assuntos a serem decididos pela assembleia geral; como todos os sócios devem ser convocados para a respectiva reunião, o proprietário, se a lei não confere apenas ao usufrutuário o direito de intervir e votar nas reuniões de sócios, poderá, por si, defender os seus legitimos interesses.

Isto mostra que a invocação daquele princípio directivo e orientador nem sempre basta para chegar a conclusões concretas e certas; ele não é chave que possa abrir todas as portas; é um instrumento que deve sempre ser utilizado para, com os outros elementos, permitir que se. atinjam resultados aceitáveis. 
E se há uns direitos e obrigações, que cabem ao usufrutuário, e outros que cabem ao nu-proprietário, outros há que cabem a ambos.

Assim, ao passo que os direitos consignados nos $\mathrm{n}^{\circ}$ s. 1 e 2 do art. 119 do Cód. Com.: - a haver a parte do dividendo dos lucros que lhe competir pro rata temporis - dia a dia, em proporção do tempo que dura o usufruto (Cód. Civ., art. 2205), e a escolher os administradores e tomar-lhes contas - competem ao usufrutuário os dos $\mathrm{n}^{\circ}$ s. 3 e 4 do mesmo art. - examinar a escrituração e os documentos correspondentes às operações sociais e fazer as reclamações ou propostas, que julgar convenientes e as obrigações impostas nos $\mathrm{n}^{\mathrm{o}} \mathrm{s} .3$ e 4 do art. 118 do Cód. Com. - exercer cargos sociais e prestar contas do exercício do mandato social - competem a ambos, podendo cada um exercer esses direitos e cumprir essas obrigações só por si, sem necessidade do concurso do outro.

Consequentemente, qualquer deles tem o direito de, com outros sócios, requerer um inquérito social, nos termos do art. 149 do Cód. Com. e 1531 do Cód. de Proc. Civ.

Quando, nos casos em que a lei o permite, os sócios podem receber durante algum tempo juro certo (Cód. Com., art. $182 \S 2^{\circ}$.), é óbvio que esse juro pertence ao usufrutuário (12).

Mas se a lei permite ou impõe um certo reembolso de capital (13), óbvio é também que as quantias reembolsadas pertencem, em propriedade ou em usufruto respectivamente, ao nu-proprietário e ao usufrutuário.

(12) Contra, com o erróneo fundamento de que não representam lucros da sociedade, reconhecendo aliás que se trata de "un derecho pariente al dividendo", SANchez Torres, ob. cit., pág. 64 .

(13) O Dec. de 21 de Outubro de 1907, ao regular a constituição das sociedades mútuas de seguros, estabelece que o pacto social deve indicar a importância do capital de garantia e as condições da sua amortização. 
A este cabe também o gozo das regalias especiais que algumas sociedades dão aos sócios, por exemplo, as reduções de preços das entradas nos espectáculos públicos dados pelas respectivas emprêsas.

Duas considerações ainda, relativas ao critério geral com que devem ser encarados estes problemas, convém ter presentes: - uma é que a legislação fiscal, inspirada por idéias peculiares e desprezando a técnica e mesmo os princípios jurídicos, não deve, em regra, ser invocada para a solução desses problemas (14); - outra é que a doutrina de que as questões entre proprietário e usufrutuário, porque o usufruto é elemento desintegrador da propriedade normal, devem, em caso de dúvida, decidir-se a favor da plenitude da propriedade (15) só deve ser aceita com ressalva de, tendo em conta o titulo constitutivo do usufruto - contracto gratuito ou oneroso, testamento e lei se atender às regras legais e doutrinais sobre interpretação.

5 Dentre os problemas relativos ao usufruto de acções, partes sociais e quotas, uns há que são comuns às três referidas espécies de sociedades, embora possam ter soluções diferentes em relação a cada uma, e há outros que são próprios, ou exclusivos de uma ou outra delas.

Não temos a pretensão de versar aqui todos esses problemas; ocupar-nos-emos apenas de alguns, dentre os mais importantes, quer dos que são comuns a todas, quer dos que apenas a umas ou outras respeitam.

O primeiro, que se nos depara e alguns legisladores têm resolvido ou procurado resolver e que mais discutido

(14) Ambroise Colin, De la notion du revenu en matière de legislation fiscale; Croizat, La notion de fruit en droit privé et la notion de revenus en diroit fiscal; Sanchez Torres, ob. cit., pág. 81.

(15) Sanchez Torres, ob. cit., pág. 97 e Sentença do Tribunal Supremo espanhol de 25 de Junho de 1943, por ele citada. 
đêm sido pelos tratadistas, é o da intervenção dos usufrutuários ou dos proprietários nas reuniões de sócios.

Claro é que, se se partisse do princípio de que o usufrutuário não é sócio, o problema teria sem hesitação uma resolução negativa, a não ser nos países, cujas legislações o resolvem por forma expressa em sentido diferente.

Mas esta circunstância mostra que o caso não é tão simples como poderá parecer.

Muito ao contrário, é tão complicado que são numerosas as soluções que os autores e as legislações lhe têm dado.

6 Antes de as expormos e apreciarmos, cumpre ter em atenção o caso especial do usufruto de acções, em que há a considerar duas hipóteses: - a de serem as acções nominativas e a de serem ao portador.

Se porém, a lei, dispiuser que, no caso de usufruto de acções ao portador, o proprietário tem o direito de exigir que a sociedade Ihe passe um outro título representativo do usufruto, ou que converta os títulos ao portador em nominativos com a indicação de que estão sujeitos ao usufruto (16), já as duas hipóteses se equivalem.

Se a lei não conceder esse direito, a posse da acção, quer nominativa, quer ao portador, pertence ao usufrutuário.

Mas se a acção fôr nominativa, o ónus do usufruto deve constar do título, por meio de endosso e averbamento, e do livro de registo de acções (Cód. Com., 168).

$\mathrm{E}$, portanto, embora a acção esteja na posse do usufrutuário, o proprietário pode, em relação à sociedade, exercer os direitos, que lhe competirem como tal, sem que a

(16) Antigo Cód. italiano, art. 498; o art. 2025 do Cód. Civ. italiano de 1942 dá ao usufrutuário de uma acção nominativa o direito de exigir que lhe passem um título especial representativo :do usufruto. 
sociedade possa alegar ignorância, ou possa negar-se $a$ reconhecer-lhe essa qualidade.

Se a acção fôr ao portador, como está em poder do usufrutuário, o proprietário, sempre que pretenda exercer algum dos direitos, que lhe competem, tem, não só de provar o ónus do usufruto, mas ainda de apresentar $o$. respectivo títūo.

Como, a maior parte das vezes, isto não será possível, segue-se que o usufrutuário tem de cumprir a obrigação, que lhe impõe o art. 2240 do Cód. Civ., de avisar o proprietário de qualquer acto de terceiro, de que tenha notícia e que possa lesar os direitos do proprietário, respondendo, se o não fizer, por perdas e danos.

E terá sempre de responder para com o proprietário por todos os prejuizos, que lhe causar.

$\Xi$ de recordar que o usufrutuário de uma acção ao portador não só pode legalmente alienar o seu usufruto, mas também pode ilegalmente vender a própria acção. Certamente responde pelo abuso praticado, mas essa responsabilidade não se poderá efectivar quando o usufrutuário não tenha bens suficientes, e se tiver sido dispensado de prestar caução, ou não lhe tiver sido exigida.

Seja como fôr, é óbvio que, para que tanto o proprietário como o usufrutuário possam exercer cabalmente os direitos, que respectivamente lhes competirem, deve a lei conferir a um e a outro titulos representativos da nuapropriedade e do usufruto.

Não os havendo, como, repetimos, é ao usufrutuário que cabe a posse da acção. 0 exercício dos direitos do proprietário para com a sociedade será muito precário, a não ser que entre ele e o usufrutuário haja razoável entendimento.

Também nos parece que a sociedade deve permitir a um e outro o exercício dos respectivos direitos, desde que seja feita a prova de que certos títulos ao portador. 
estão sujeitos a usufruto e desde que sejam apresentados os títulos, ou por outra qualquer forma a sociedade possa assegurar-se de que da sua permissão nenhum prejuizo lhe advirá ou advirá a terceira pessoa.

É frequente dispôrem os estatutos das sociedades por acções que os títulos ao portador devem ser depositados na própria sociedade ou em determinado estabelecimento de crédito, com certa antecedência para que o sócio possa intervir nas assembleias gerais.

Se o usufrutuário faz o depósito, bem está. Se o não faz, não poderá o proprietário obrigá-lo e não poderá intervir na respectiva assembleia geral.

Segundo o art. 1081 do Cód. Civ. alemão, a posse da acção ao portador onerad'a de usufruto pertence, em conjunto, ao usufrutuário e ao proprietário e a posse dos coupons de dividendos pertence ao usufrutuário, e, segundo o art. 1082 do mesmo Cód. se assim fôr pedido pelo usufrutuário ou pelo proprietário, deve a acção ser consignada num depósito público, com a condição de que não poderá ser exigida senão pelo usufrutuário e pelo proprietário conjuntamente, podendo também o usufrutuário exigir que seja depositada no Banco do Império, ou num outro qualquer lugar escolhido de acôrdo por ele e pelo proprietário.

Alguns autores francêses (17) entendem que o usufrutuário é obrigado a fazer conhecer ao proprietário os $\mathrm{n}^{\circ} \mathrm{s}$. dos respectivos títułos, mas Albert WaHL (18) diz que é duvidoso o valor teórico desta exigência, que não vê qual seja a sua utilidade e que a sua sanção é nula. Em certos casos, em que o próprio título constitutivo indica esses $\mathbf{n}^{\circ}$ s. tal exigência é escusada e, nos outros, é insuficiente.

(17) Citados por AlberT Wahl, Traité, th. et prat. des titres au porteur, vol. 2. ${ }^{\circ}$, n.o 1154.

(18) Lug. cit. 
O que nos parece é que deverá o usufrutuário de acções ao portador ser obrigado a depositá-las na própria sociedade, não só sob pena de responder por perdas e danos, mas ainda, no caso de se poder fazer perante ela a prova de que certos títulos estão sujeitos a usufruto, não permitir que o usufrutuário exerça os direitos, que lhe competem, sem que deposite no cofre social os respectivos títulos.

É de harmonia com as considerações, que acabamos de fazer, que devem ser entendidas as que se seguem sobre os direitos de intervir e votar nas reuniões das assembleias gerais.

7 Focando agora estes problemas, vejamos que soluções lhes têm sido dadas e se, além delas, outras poderão melhor corresponder ao devido respeito pelos legítimos interesses do nu-proprietário e do usufrutuário.

a) Há quem entenda (19) que nem um nem outro podem votar, porque, sendo o direito de voto exclusivo, a acção está dividida e só a plena propriedade dela pode. justificar o exercício de tal direito - doutrina esta que nos parece escusado refutar pela sua manifesta improcedência, pelos prejuizos, a que daria lugar, e pelo abandono a que tem sido votada;

b) Sustentam uns autores que a representação das acções nas assembleias deve pertencer exclusivamente ao proprietário: - Lyon Caen et Renault (20), Rousseau (21), arthuys (22), José Tavares (23), Pereira de Vasconce-

(19) BiermanN Sachsenrecht, 1.a ed., citado por Sanchez Torres, ob. cit., pág. 176.

(20) Traité de droit com., vol. 2.0, n.o 845.

(21) Des soc. com. françaises et étrangères, n.o 2326.

(22) Traité des soc. com., t. 2.0., pág. 37.

(23) Soc. e empresas com., 2.a ed., pág. 544. 
los (24), Rafaelli (25), Albert Wahl (26), Garrigues (27), Dernburg (28), etc.

Esta tese, aliás sustentada por numerosos e autorisados autores, não está de harmonia com o regime legal do usufruto, e despreza os direitos inerentes ao gozo da cousa usufruida, sendo manifestamente insuficiente a limitação, que alguns autores pretendem que se estabeleça ao direito do proprietário - de não prejudicar o usufrutuário.

Mas Pereira de Vasconcelos reconhece que, na prática, a sua opinião não é seguida; e ALBERT WAHL, referindo-se apenas aos títulos ao portador, também reconhece que, na prática, é o usufrutuário que exerce o direito de intervir nas assembleias gerais sem que ninguém o possa impedir.

c) Sustentam outros que o usufrutuário e o proprietário devem proceder de acôrdo, indo só um deles à assembleia, como no caso de compropriedade, e que, na falta de acôrdo, devem os tribunais resolver (29); havendo quem acrescente que, se ambos se apresentarem na assembleia, o direito de votar deve ser recusado a um e a outro, e que, como a intervenção nas assembleias gerais, quer ordinárias, quer extraordinárias, é um acto de administração, deve, em princípio, e no caso de competição, ser esse direito reconhecido, de preferência, ao usufrutuário (30).

d) Outros ainda têm sustentado que nuns casos a representação das acções cabe ao usufrutuário e noutros

(24) Manual das ass. gerais das soc. anónimas, pág. 215.

(25) Le societá commerciali, pág. 311.

(26) Ob. e vol. cit., n.o 1160.

(27) Tratado cit., I, 2., pág. 958.

(28) Burgerliches Recht, vol. 3.0, pág. 637.

(29) Bourcart, De l'organisation et des pouvoirs des ass. gén. dans les, soc. par actions, pág. 108; Lavasseur, Soc. civ. et com., $5 .{ }^{a}$ ed., n. ${ }^{\circ}$ 904; ClÉment, Des pouvoirs des assem. gén. dans les soc. par actions, n.o 10.

(30) Houpin et Bosvieux, Traité gén. des soc. civ. et com., จㅇ. 2.: n: 1125. 
cabe ao proprietário, mas dividem-se ao determinar quais os casos, em que qualquer deles, usufrutuário e proprietário, deve intervir: - opinam uns que o usufrutuário deve intervir nas assembleias gerais ordinárias e que o proprietário deve intervir nas assembleias gerais extraordinárias (31); outros opinam que um e outro devem ter o direito de voto, o usufrutuário quando se trate de problemas que respeitem à mera administração da acção, e o proprietário quando se trate de problemas, que respeitem à sua disposição ou à sua propriedade (32); Cunha Gonçalves entende que é ao usufrutuário que compete a intervenção em todas as assembleias gerais em que se não discuta assunto que respeite à propriedade das acções; quando qualquer deliberação a tomar lhe respeite, a representação das das acções compete a ambos, mas só um deles poderá votar conjuntamente, ou terá de votar um deles com o mandato do outro, por analogia do que a lei dispõe para .) caso de compropriedade das acções (32); - o Visconde DE CARNAXIDE, considerando, como com razão o fazem muitos outros escritores, que em ambas as duas referidas espécies de asembleias podem ser afetados os direitos do usufrutuário e do proprietário, entende que o melhor critério, para não proteger um à custa da desproteção do outro, consiste em deixar os dois ser juizes do que lhes convém, os quais, certos de que a lei se não interpõe entre eles, terão de chegar ao melhor acôrdo para não abandonarem na assembleia a defesa da sua causa comum (34).

(31) Thaller, Anuales de droit com., 1893. II, pág. 269, que depois, como a seguir veremos, mudou de opinião; Pic, Sociétés comerciales, n.o 1275, SANchez ToRres, ob. cit., pág. 182 e 194; Siville, Traité des sociétés anonymes belges, vol. 1.०, n.o 1182; etc.

(32) Bezard-Folgas, Traité du contentieux des transferts d'actions et d'obligations nominatives, n.o 14; STAMMLER, citado por Sanchez Torres, ob, cit., pág. 181.

(33) Com. ao Cód. Com., vol. 1., pág. 459.

(34) Sociedades anónimas, n. 94. 
Foi esta a solução adoptada pelo Dec.-Lei brasileiro no. 2627, de 26 de Setembro de 1940, que, no seu art. 94, dispõe: - "No usufruto de acções, o direito de voto sòmente poderá ser exercido mediante prévio acôrdo entre o proprietário e o usufrutuário". Esta disposição é inaceitável, por insuficiente. Como observa Alberto Asquini (35) a disposição do art. 10 do R. D. italiano $\mathrm{n}^{0}$. 1364, de 7 de Junho de 1923, que o art. 84 do Dec-lei brasileiro reproduziu, refletia a perplexidade da doutrina sobre o problema. Mas, como veremos adiante, a solução dada pelo art. 2352 do Cód. Civ. italiano de 1942 ainda reflete essa perplexidade.

e) Finalmente, outros, (36) com base na ideia defendida por GIRARD (37) de que a intervenção nas assembleias gerais é sempre um acto de administração, sustentam que ela compete apenas, e sempre, ao usufrutuário.

É esta a solução adoptada pela jurisprudência francesa (38), pelo art. 690 do Código suiço das Obrigações, que acrescenta que o usufrutuário é responsável para com o proprietário se não tomar os interesses deste em consideração, e pelo art. 2352 do Cód. Civil. italiano de 1942, que, todavia ressalva convenção em contrário.

quela responsabilidade será difícil de determinar e, por vêzes, não poderá efectivar-se integralmente.

A convenção contrária ressalvada nesse art. do Cód. Civ. italiano pode ser exarada tanto no pacto social, como no título constitutivo do usufruto; mas raro será vê-la exarada num ou noutro título. Além de que, raro será também que essa convenção dê ao problema uma solução melhor.

(35) Usufrutto di quota sociali e di azioni, na Riv. di dir. com., t. XVI, 1947, pág. 12 e segs., signanter pág. 23

(36) Thaller, Traité élem. de droit com., n.o 686; Houpin, Traité des sociétés, vol. $2 .^{\circ}$, n. 926 ; R. Mrchel, Rec. Jur. des Sociétés, 1924, pág. 136; Planiol, Ripert e Picard, Traité pratique de droit civil français, vol. $3 .{ }^{\circ}$, n. ${ }^{\circ} 807$; etc.

(37) Le droit d'assister aux assemblées générales.

(38) Chambaz-Leblond, Précis des sociétés, n.0 1317, pág. 374. 
Em todo o caso, é de estranhar que esse Cód. não tenhil, ao menos, feito distinção entre assembleias gerais ordinárias e extraordinárias, quando não quisesse ir mais longe e providenciar diferentemente para os casos de se tratar apenas de questões de mera administração e de questões interessando o próprio domínio da acção.

Com razão, pois, GaSperoni (39) criticou a disposição nesse sentido e não nos parece que seja de atender a desculpa dada por Alberto Asquini (40) dizendo que a lei preferiu uma disposição unívoca a uma disposição casuística, tendo presente que, entrando no campo das distinções, se deveria atender também às matérias da competência das assembleias extraordinárias, pois que nem todas as modificações do pacto social põem em causa o interesse do proprietário.

Certamente a simples distinção entre assembleias ordinárias e extraordinárias não é bastante, especialmente nos paises, onde, como em Portugal, há divergências na doutrina sobre quando é que se podem considerar extraordinárias asassembleias e onde, se os estatutos não dispuserem o contrário, todos os assuntos susceptíveis de serem tratados numa assembleia geral extraordinária também o podem ser numa assembleia geral ordinária (Cód. Com., art. 179 $\S$ ún., $\mathrm{n}^{\mathrm{o}} .3^{\circ}$.).

Mas parece-nos que o problema pode ter uma soluçãa mais concreta, que adiante exporemos.

Por vezes o legislador terá de deixar à doutrina e à jurisprudência a solução de alguns problemas, mas só o deve fazer excepcionalmente, por impossibilidade ou por indiscutível conveniência e não apenas por comodidade.

Ainda no campo da doutrina, há a registar duas opiniões que fazem certas restrições à solução de pertencer ao usufrutuário o direito de intervir nas assembleias de sócios.

(39) Le azione di società, pág. 200.

(40) Ob. e vol. cit., pág. 24. 
Adriano Antero (41), depois de reconhecer que o problema não pode considerar-se resolvido pelo disposto no art. $168 \S 2 .^{\circ}$ do Cód. Com., porque esse $\S$ se refere a hipótese diferente, qual é a de haver compropriedade, e depois de informar que, a fim de evitar complicações, nos estatutos de muitas sociedades se dispõe que, em caso de usufruto, serão as acções vendidas transferindo-se o usufruto para o respectivo produto, sustenta que é ao usufrutuário que assiste o direito de voto; e que, se a votação afecta simplesmente o usufruto, nada tem com isso o proprietário, mas, se pudér influir também na propriedade, como nem o proprietário nem o usufrutuário podem, só por si, transformar ou modificar o objecto do usufruto, segundo se deduz dos arts. 2.217 e 2.227 do Cód. Civ., devem combinar ambos o modo da votação; e acrescenta que - o usufrutuário é o que vota; mas não o deverá fazer, comprometendo a propriedade, sem acôrdo com o proprietário; se este não quiser concordar, o recurso, que assiste àquele, é votar contra tudo que possa comprometer a propriedade.

Com razão Adriano ANTERo considera inaplicável ao caso o disposto no $\S 2 .^{\circ}$ do art. 168 do Cód. Com., segundo o qual, no caso de compropriedade de uma acção, nominativa ou ao portador, a sociedade não será obrigada a averbar e a reconhecer a respectiva transferência enquanto os comproprietários não elegerem um de entre si que os represente para com a sociedade quanto ao exercício dos direitos e cumprimento das obrigações que lhes piertencem, por isso que, na compropriedade, em regra, os comproprietários têm os mesmos interesses, ao passo que, no usufruto, o usufrutuário e o proprietário têm, em regra, interesses diferentes, senão mesmo, por vêzes, antagónicos.

A norma do $\S 2 .^{\circ}$ do art. 168 pode, no entanto, ser aplicada quando o usufruto de uma acção, parte ou quota social, pertencer a mais de uma pessoa.

(41) Comentário do Cód. Com. Português, 2.a ed., vol. 1.`, pág. 272. 
A informação que Adriano Antero fornece, relativa à disposição dos estatutos mandando vender as acções, quando sejam objecto de usufruto, não a podemos confírmar, pois que nunca deparámos com ela nos muitos estatutos que temos examinado. ciente.

E, quanto à solução proposta, é, por demais, insufi-

Venezian (42), partindo do princípio de que deve reconhecer-se ao usufrutuário de uma acção ao portador, como investido que está formalmente da sua propriedade, quantos direitos pode exercer o accionista com respeito à sociedade, sustenta que lhe cabe o direito de intervir nas assembleias gerais, sem que a sociedade lhe possa recusar ou possa admitir que o proprietário o exerça em concorrência com êle, mas sustenta também que, com respeito ao proprietário, tem o usufrutuário obrigação de abster-se de exercer as faculdades, de que está investido por virtude da posse do título, que possam alterar a substância do direito e responderá para com êle se lhe não participa a convocação para as respectivas assembleias e se lhe não proporciona a possibilidade de intervir, entregando-lhe temporàriamente a acção (43).

Esta doutrina, salvo na parte relativa à referida abstenção, só é aplicável, como é óbvio, ao usufruto de títulos ao portador.

8 Preferimos a doutrina da alínea $d$ ), na segunda das modalidades acima mencionadas, mas precisando a prova como investido que está formalmente da sua propriedade, de voto deve caber ao usufrutuário, ou ao proprietário.

Baseamo-nos, não só na natureza jurídica do usufruto, mas também nas disposições do Cód. Civ., que o regulam, e nas do Cód. Com., reguladora da matéria de sociedades.

(42) Dell'usufrutto, dell'uso e dell'abitazione, n. 299.

(43) Usufruto, uso e abitazione, n. 299. 
Entendemos que tanto o proprietário como o usufrutuário podem usar do direito de intervir nas assembleias gerais; o usufrutuário, por isso que, nos termos do já cit. art. 2206 do Cód. Civ., tem o direito de gozar de todos os direitos inerentes à coisa usufruida, salvo aquêles que sejam incompatíveis com a natureza jurídica do usufruto, como é o da alienação da própria coisa usufruida, e o proprietário, porque, como se vê do art. 2240 do mesmo Cód., se os seus direitos estiverem ameaçados, pode agir para evitar a lesão e, consequentemente, pode reagir quando êles forem ofendidos.

Ora o direito de intervir nas assemb]eias gerais, assistindo, discutindo e votando e, consequentemenle, o direito de requerer em juizo a suspensão e anulação das deliberações sociais, que forem contrárias ià lei ou ao pacto social, nã̃) sâo por lei excluidos do espaç̣o juridico, em que o msufrutuário se pode mover, nem são prejudicados por aquela incompatibilidade.

Dispondo o art. 2240 do Cód. Civ. que o usufrutuário ë obrigado a avisar o proprietário de qualquer facto de terceiro, de que tenha noticia, que possa lesar os direitos do proprietário, e que, se o não fizer, responderá por perdas e danos, claro é que implicitamente lhe impõe: - 1. ${ }^{\circ}$, que não lese êle próprio os direitos do proprietário; $2^{\circ}$ que os defenda, quando o proprietário não possa fazê-lo. Se, como já observámos, se trata de assunto a ser discuticlo e resolvido em assembleia geral, como para ela é convocado o nu-proprietário, o aviso do usufrutuário é escusado, embora êle o prossa fazer, por mera cautela, on quando tenha interesse, embora indirecto, em que o proprietário proceda na defesa dos seus direitos.

$\mathrm{Na}$ reunião da assembleia geral podem compalecer tanto o usufrutuário como o proprietário; ambos poderão discutir os assuntos que entenderem, pois que da discussão dos problemas relativos à administração pelo proprietário e dos relativos à propriedade pelo usufrutuário nenhum prejuizo poderá resultar, e será difícil pôr-lhe limite, mas 
só um poderá votar - em regra o usufrutuário, ou o proprietário quando se tratar de deliberações que possam of ender o seu direito de propriedade, cabendo ao presidente da assembleia geral, com recurso para a própria assembleia, e da decisão desta para os tribunais, o decidir quando deve votar um ou outro.

Por esta forma serão resolvidas as dificuldades que na aplicação desta doutrina podem surgir e que não são tão graves que levem a pôr de parte a solução, que de todas é a mais jurídica e a mais equitativa.

Consequentemente, pois que com o direito de voto é conexo o da defesa judicial dos respectivos direitos, qualquer deles, o usufrutuário ou o proprietário, pode requerer, nos termos dos art. 146 e 186 do Cód. Com., a suspensão e a anulação das deliberações que respectivamente respeitam aos direitos e obrigações de cada um.

José Tavares, partindo da idéia de que o usufrutuário não é socio, entende que êle não tem esses direitos.

Mas entende também que, para garantir a satisfação plena do seu direito aos dividendos e lucros, pode o usufrutuário acionar a sociedade pelo emprego ilegal de uma parte dos lucros realizados, para pedir a determinação e fixação dos dividendos no tempo e pelo modo estabelecidos na lei e no contrato social, e pedir nas mesmas condições o pagamento da quota, que lhe pertence, e, enfim, para se opôr a qualquer outro acto que ilegalmente evite ou diminua a existência dos lucros a dividir.

Esta opinião é inaceitável, pois que por ela o usufrutuário teria mais direitos e não estava sujeito às restrições, que a lei confere e impõe ao nu-proprietário, dando lugar à insegurança das deliberações sociais, que a todo o tempo poderiam ser judicialmente atacadas e revogadas.

Nos países em que, segundo a lei, só o usufrutuário tem o direito de voto, o seu procedimento deve ser pautado pelas respectivas disposições legais, quando elas não se limitem a conferir-lhe aquele direito. 
Assim, pelo art. 690 do Cód. suiço das obrigações, o usufrutuário responde para com o proprietário se não tomar os seus interesses em equitativa consideração - fórmula esta muito vaga, que não defende devidamente os interesses do proprietário e que colocará por vezes o usufrutuário numa situação dificil, dada a eventual incompatibilidade entre os seus interesses e os do proprietário.

o Cód. Civ. italiano limita-se, como vimos, a conferir o direito de voto ao usufrutuário resalvando, todavia, a convenção contrária.

Desta norma, e quando não haja tal convenção, assim como da conexão que existe entre o direito de voto e o de impugnar as deliberações ilegais, deduz Alberto Asquni (44) que o usufrutuário tem legitimidade para as acções tendentes a essa impugnação e que, no exercício dessas acções, ele age, porém, não só no interesse próprio, mas também como gestor do nu-proprietário, - que tem um interesse próprio na legalidade das deliberações sociais e desse exercício assume o usufrutuário a respectiva responsabilidade; e só na inércia do usufrutuário, o nu-proprietário poderá legitimar-se para o exercício dessas acções, nos termos do art. 1015 do Cód. Civ., sempre naturalmente no pressuposto de que o usufrutuário tenha estado ausente ou discorde da deliberação.

Tudo isto nos parece confuso e complicado. Achamos preferível as soluções, que, no silênncio da legislação portuguesa, acima propomos.

8 Outros problemas mais, relativos ao direitos do usufrutuário de acções, ou de partes, ou de quotas sociais, têm sido estudados por alguns autores.

Planiol, Ripert et Picard (45), começando por assinalar as numerosas dificuldades da matéria, dão como fir-

(44) Usufrutto di quota social e di azioni, na Riv. di dir. com., t. XVI, 1947, pág. 12 e segs.

(45) Traité pratique de droit civil français, t. $3 .^{\circ}, \mathrm{n}^{\circ} \mathrm{s} 791$ e segs. 
memente estabelecido pela doutrina e pela jurisprudência francesas este princípio, que, em seu entender, deve ser aceite: os benefícios de uma empresa comercial ou industrial não são frutos "par essence": tornam-sé tais logo que, provindo de operações repetidas, têm sido transformados pela sociedade em rendimentos periódicos.

"Le caractère des bénèfices", dizem êsses escritores, "dépend donc de l'aménagement que leur impose la société: elle en traite certains comme des fruits et les destine à la consommation; elle capitalise les autres et les incorpore à l'actif social. Par suite, l'usufruitier, jouissant de la chose qui forme l'object de son droit comme en jouissait le propriétaire, est tenu dès lors de respecter le pacte social qui va gouverner les rapports avec le nu-propriétaire, devra supporter les conséquences de cet aménagement, à la condition qu'il ait lieu en conformité du pacte social. Son droit portera sur les bénéfices auxquels la société atribuera le caractére de fruit; il ne s'étendra pas à ceux qui auront été l'object d'une capitalisation.

"Ce principe doit être appliqué aux différentes situations qui peuvent se présenter".

$\mathrm{E}$ a seguir estudam vários problemas, chegando às seguintes conclusões:

a) que o usufrutuário tem direito aos dividendos, mas não às quantias tiradas dos lucros, em que sejam constituidas as reservas distribuidas pelos sócios, salvo as que tenham sido criadas para complemento de dividendos.

b) quando a sociedade, emitindo novas acções, estabelece um preço superior ao valor nominal das acções a pagar pelos novos accionistas, se as importâncias dêsse acréscimo de preço entram nos cofres da sociedade para constituir reserva ou aumentar as reservas existentes, nenhum direito tem a elas o usufrutuário; se são distribuidas pelos sócios, devem ser atribuidas ao proprietário e ao usufrutuário, àquele em propriedade e a este em usufruto.

c) quando, na emissão de novas acções, os antigos sócios têm o direito de preferência para a aquisição delas, 
êsse direito não pertence ao usufrutuário, ainda mesmo que o proprietário não queira usar dele.

d) o usufrutuário tem o direito, na medida da sua parte, aos lucros realizados pela sociedade e postos comto tais à disposição dos sócios, mas não tem direito algum sôbre os lucros regularmente transformados em capitais, designadamente sôbre as reservas constituidas em conformidade com as disposições estatutárias.

Referindo-se a estes vários problemas, CunHA GonçALves (46), que, de uma maneira geral, aceita as soluções dadas por aquêles escritores, dizendo até que "ainda mesmo que uma parte dos lucros sociais tenha sido empregada em melhoramentos da empresa, será inadmissivel qualquer pretensão do usufrutuário das acções, porque o acionista só tem direito à sua parte dia soma destinada, no balanço anual, a ser distribuida como dividendo", procura fundamentá-las, à face do nosso Cód. Civ., dizendo que os benefícios pecuniários, que não sejam dividendos, não são frutos civis, porque, diz, não têm as respectivas caracteristicas; são acréscimos eventuais do capital empregado nas acções; falta-lhes a periodicidade própria dos rendimentos.

Essas características indica-as CuNHA GonçAlves em nota ao art. 2202 do Cód. Civ. (47), dizendo que a noção de frutos tem como elementos a separabilidade, a periodicidade, a reproducibilidade da substância e a inalterabilidade, mas logo acrescenta que êstes elementos não têm caracter de absolutos, porque podem alguns faltar em certos frutos; e antes, ao anotar o art. 495 do mesmo Cód. (48), afirma que - "a palavra frutos, tanto em matéria de posse, como de propriedade, é empregada pelo legislador no amplo sentido de todo e qualquer rendimento da cousa possuida, segundo o seu destino económico, seja ou não periódica, que. se possa obter sem a destruição ou diminuição dessa cousa."

(46) Trat. de dir. civ., vol. 11, pág. 415 e 416.

(47) Ob. e vol. cit., pág. 374.

(48) Ob. cit., vol. 3.o, pág. 613. 
As contradições são evidentes, pois que o $\S$ ún. do art. 2202 dispõe que "os frutos naturais, industriais e civis se-

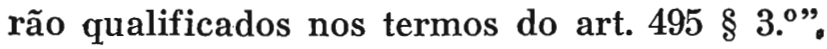

Ainda, ao anotar êste mesmo art. 495 (49), CunHA Gonçalves considera frutos civis os lucros líquidos do estabelecimento comercial; ao anotar o art. $2202 \mathrm{diz}$ que com razão se tem definido (Venezian) frutos civis como "toda a classe de rendimento, que se obtém de uma cousa ou de um direito, em virtude de um vínculo jurídico", e entende que o usufrutuário pode utilisar-se: $a$ ) de plantas de viveiro (art. 2213); b) de pedras de uma pedreira para as aplicar em reparações ou obras da cousa usufruida (art. 2213) ; c) da firma, nome, marcas, sinais, desenhos e modelos de um estabelecimento fabril ou comercial (art. 2214); de parte de um tesouro descoberto no terreno ou edifício usufruido (art. 2216) - o que tudo é também contraditório com aquela sua doutrina, que restringe os direitos do usufrutuário de acções ou de uma quota a receber os dividendos e as reservas constituidas para complemento dêles.

A noção, que o nosso Cód. dá, de frutos civis, não justifica as restrições que resultam daquêles elementos que Cunha Gonçalves lhes atribui, e as disposições do mesmo Cód. sobre os direitos do usufrutuário também não justificam, a nosso ver, a doutrina restrita que esse escritor adopta.

Mas foquemos separada e especialmente alguns dos mais importantes problemas que podem surgir, começando pelo das reservas que é o mais complicado.

10. Alguns Autores (50) sustentam que os preceitos do pacto social, que admitam ou imponham a formação de

(49) Ob. cit. vol. 3., pág. 615.

(50) Pacifici-Mazzoni, Distinzione dei beni, n. 377 e seg., e MANDUCA, no Filangieri, 1880, pág. 458, citados por Venezian, Isufruto, uso e abitazione, wol. 2.0, n.० 299. 
reservas com todos ou com parte dos lucros do exercicio, não podem frustrar o direito essencial do usufrutuário aos frutos, que são constituidos pelos lucros a repartir pelos sócios, e que o pacto ou a lei, que ondenem a constituição de reservas, não podem ter outro ef eito senão diferir a distribuição dos lucros, a percepção dos frutos; por conseguinte, não pode o usufrutuário da acção exercer o seu direito aos frutos impugnando a formação das reservas e pretendendo uma antecipação proporcional sôbre os lucros do exercício, mas pode, quando a sociedade se dissolver, exercer contra o proprietário o direito de ser compensado da parte correspondente das reservas que aumentam o valor da respectiva parte na sociedade; e, quando a sociedade se não dissolve durante o usufruto, pode esse direito ser exercido quando o usufruto terminar.

Venezian (51) discorda desta doutrina, sustentando esta outra: - numa sociedade pror acções não há a necessidade jurídica de que se dividam pelos sócios todos os lucros e não tem a natureza de renda (frutos) a porção que legitimamente se subtraia à divisão, pelo que o usufrutuário carece, em qualquer tempo, do direito de fazer sua a parte correspondente e tem que restituir, ao terminar o usufruto, a acção aumentada em proporção da importância, a que, com as reservas, ascender o activo social, e só quando a sociedade se dissolva durante o usufruto, êle receberá a acção valorisada, mas que terá de ser entregue ao proprietário quando o usufruto termine; à divisão dos lucros não podem subtrair-se legitimamente mais do que os necessários para constituir as reservas que a própria lei e os estatutos, que são lei para os sócios e seus representantes, mandem fazer; - quando a constituição de reservas não esteja prevista no pacto social, a sua criação, mesmo com o propósito de aumentar o crédito e a solidez da empresa e assegurar assim maiores lucros nos exercícios futuros, significa sempre um sacrifício dos interesses individuais.

(51) Lug. cit. 
que a maioria não pode impor; contra a sua deliberação deve facultar-se aos interessados o direito de oposição e, especialmente, ao usufrutuário, que não tem compensação da privação actual na esperança de futuros lucros maiores.

Esse direito de oposição às deliberações que criam reservas não previstas pelos estatutos é atribuido aos sócios em geral, por vários autores e designadamente por VivanTE (52), segundo o qual as cláusulas dos estatutos, ou, no seu silêncio, as disposições da lei determinam a medida em que cada accionista deve sacrificar a sua parte nos lucros ao futuro da empresa e, antes de acmentar este sacrifício por uma derrogação do pacto social, haverá que modificá-lo com as precauções prescritas na lei para proteger as minorias.

Alguns comercialistas, porém, ressalvam o caso de uma necessidade precisa e nitidamente determinada, que imponha a criação duma reserva para evitar uma crise financeira na sociedade.

Esta ressalva, como qualquer outra análoga, é contrária à lei, dá lugar ao arbitrio e pode causar prejuizo a alguns sócios.

$\mathrm{E}$, desde que se entenda que a assembleia geral pode criar a reserva, sem ofender a lei ou o pacto social, nem sequer os sócios prejudicados poderão requerer a anulação da deliberação, salvo o caso de abuso de direito de que adiante trataremos.

Em França a opinião dominante era quue a constituição de uma reserva extraordinária permanente, prejudicando a distribuição dos lucros pelos sócios, importava uma modificação substancial, que excedia os poderes da assembleia geral, e que só podia, portanto, ser deliberada pelo voto unânime dos sócios; ùltimamente, a maioria dos auto-

(52) Traité de droit com., vol. 2.०., n.० 509, onde são citados, no sentido da sua opinião, a jurisprudência alemã e Autores alemães. Além dêsses, Houpin er Bosvieux, ob. e vol. cit., n. ${ }^{\circ}$ 1354. pág. 582; Visconde DE GARNAXIDE, olb. ci.t., pág. 414, etc., etc. 
res, segundo informa Paul PIc (53), entende que a assembleia geral pode deliberar a formação de uma reserva extraordinária fundando-se nas leis de 16 de Novembro de 1903 e de 22 de Março de 1913, principalmente nesta última, que consignou o princípio da soberania absoluta da assembleia geral, mas ressalva os casos de ser a deliberação eivada de fraude, ou ditada, não pelos interesses da socie-dade, mas pelo desejo de ofender os direitos de certas categorias de interesses (portadores de partes do fundador, usufrutuários de acções, etc.).

Por outro lado, Vivante (54), também com outros autores (55), sustenta que o direito aos dividendos é um direito condicionado pela aprovação do balanço pela assembleia geral, que pode criar fundos de amortização e dar a quaisquer bens do activo um valor diferente, maior ou menor do que lhes tenha sido atribuido pelos administradores, sem ofender nem a lei, nem o pacto social; e, conformando-se com os preceitos legais, pode modificar os estatutos e neles afectar os lucros a novas reservas e até: decidir que êles só sejam divididos de 2 em 2 ou de 5 em: 5 anos, ou até mesmo só no fim da sociedade.

E' fundamentalmente a mesma a doutrina de AsQuini..

Entende este escritor (56) que nesta matéria a assembleia é soberana e que a lei italiana só socorre o usufrutuário conferindo-lhe o direito de voto, com o qual pode defender os seus interesses; mas, acrescenta, esse seu voto perante uma maioria contrária é naturalmente inoperante.

Continua ainda dizendo que não hả lugar a distinguir entre o caso de se acumularem os lucros pela constituição

(53) Sociétés commerciales, vol. 2.0 ${ }^{\text {n }} .^{\circ}$ 1193, pág. 679.

(54) Ob. e vol. cit., pág. 521 Garrigues, Curso de derecho mercantil, vol. 1. ${ }^{\circ}$, pág. 276, etc. Contra: VIGHI, I diritti individuali degli azionisti, pág. 163.

(55) Ob. e vol. citt., n. ${ }^{\circ} 579$.

(56) Ob. e lug. citt., 7, pág. 21. 
de reservas legais ou estatutárias, ou por imposição de leis restritivas dos dividendos, e o da acumulação provir de reservas extraordinárias, deliberadas pela assembleia além dos casos previstos pela lei ou pelos estatutos, e ainda o das reservas ocultas por aumento dos valores do activo, por isso que a medida do direito de fruição do usufrutuário é a que resulta, não só directamente da lei e dos estatutos, mas também indirectamente dos poderes soberanos da assembleia, no que respeita aos lucros a distribuir Só haverá a considerar, para lhe dar uma solução adequada, a hipótese de ser a deliberação restritiva do dividendo determinada, não por critérios objectivos adoptados no interesse da sociedade, mas com a intenção de limitar a fruição das acções pelos usufrutuários em favor do nu-proprietário. Nesta hipótese, haveria da parte da assembleia o exercício de poderes por uma causa não social, lesiva do direito do usufrutuário, e poderia dizer-se que a deliberação péca pelo vício de exesso ou desvio de poder, que é compreendido no vício de ilegitimidade latu sensiu, podendo o usufrutuário pedir judicialmente a sua anulação.

Exceptuando a primeira, todas estas doutrinas pecam, não só por terem em conta apenas o regime legal ao funcionamento das sociedades - e nem sempre - desprezando o regime legal relativo ao usufruto e, designadamente, o relativo aos direitos do usufrutuário, mas também por não atenderem a que se trata de relações entre o usufrutuário e o proprietảio, e não entre qualquer deles e a sociedade.

Outro vício comum a todas estas: - o considerarem que as deliberações sociais, pelas quais os lucros liquidos não são logo divididos pelos sócios, sendo-lhes dadas outras diversas aplicações, têm a força bastante para altera a natureza de frutos civis, que têm esses lucros.

Cabe dar lugar aqui, nesta resenha de soluções do probiema das reservas, à dada pelo Ac. do Sup. Trib. de Just. 
de 22 de Março de 1940 (51), que recaiu sobre o seguinte caso:-

Estando uma quota de $17.000 \$ 00$ sujeita a usufruto e tendo falecido o usufrutuário em 13 de Maio de 1944, os proprietários da quota intentaram uma acção contra a sociedade com os fundamentos e pedido seguintes: - que, tendo a sociedade deliberado, relativamente áquele ano, distribuir pelos sócios uma parte dos lucros correspondentes a $550 \%$ do capital social, lhes pertenciam 93.500\$00, em proporção do valor nominal da sua quota, mas que, como o usufrutuário tem direito, nos termos do art. 2205 do Cód. Civ., aos frutos civis em proporção do tempo que dura o usufruto, a eles autores pertenciam $59.267 \$ 70$ e o restante ao herdeiro do usufrutuário; mas que a sociedade, por solicitação deste, se negava a pagar-lhes essa importância de $59.267 \$ 70$ e que, portanto, pediam que ela fôsse condenada a pagar-lha.

A sociedade contestou reconhecendo a importância da dívida dos 93.500\$00, mas dizendo que, em face de uma reclamação do herdeiro do usufrutuário, tinha dúvidas sobre a quem ela era devida, e requereu que, nos termos do art. 352 do Cód. Proc. Civ., fosse ele notificado para deduzir o. seu pedido em oposição ao dos autores.

Feita a notificação, o herdeiro do usufrutuário apresentou-se em juizo a formular o seu pedido nos seguintes termos:- que, durante bastantes anos, uma parte dos lucros apresentados no fim de cada exercício não era distribuida pelos sócios e era aplicada na constituição de fundos destinados a garantir um mais profícuo funcionamento da actividade industrial e que, em relação à quota captiva de usufruto, as importâncias, com que foram constituidos esses fundos, pertencem ao usufrutuário, pois são lücros;

57. Dêste Ac., proferido no recurso no. 54207, em que eram rec. Antonio Borges da Silva Teles e recorridos o Dr. Luiz Gonzaga Freitas Monterro e outros, foram publicados apenas uns excerptos na Vida Judiciária, t 11, pág. 191. 
- que tais lucros acumulados tinham, no entanto, contribuido, pelo seu aproveitamento, para aumentar os rendimentos da sociedade e, por consequência, havia que distinguir, em cada verba de dividendo a distribuir pelos sícios a parte fosse rendimento do activo social e a que tivesse advindo da massa de lucros não distribuidos; --que aquela parte pertencia ao proprietário desde a morte do usufrutuário, mas que esta última, porque representa fundos, que pertencem na sua plenitude ao usufrutuário, a ele pertence também o respectivo rendimento; - que, consequentemente, pedia para lhe ser reconhecido o direito às "reservas" constituidas pelos lucros não distribuidos, isto é, à parte dos dividendos que se deva considerar como correspondente a esses "fundos", a fixar em liquidação da sențença.

O Ac. julgou procedente o pedido dos proprietários e condenou a sociedade a pagar-lhes a quantia pedida e improcedente o pedido do usufrutuário, com os seguintes fundamentos: - que, para se julgar procedente o pedido do usufrutuário seria preciso admitir que os "fundos", que ele próprio usufrutuário diz serem lucros não distribuidos em anos sucessivos, lhe teriam sido atribuidos, e teriam ficado na sociedade a constituir novas quotas a ele pertencentes em plena propriedade e com direito a participarem nas distribuições dos lucros futuros, mas que nada na lei autoriza tal conclusão; - que o art. 2202 do Cód. Civ. estabelece que o usufrutuário tem o direito de perceber todos os frutos civis que a cousa usufruida produzir e, segundo o $\S 3 .^{\circ}$ do art. 495 do mesmo Cód., frutos civis são as rendas ou interesses que dela provenham; - que o art. 20 da lei de 19 de Abril de 1901 estabelece que os sócios têm direito, salvo estipulação em contrário, aos lucros líquidos que resultem do balanço anual, deduzida : percentagem destinada à formação do fundo de reserva; mas que o art. 10 do pacto social preceitua que para amortizaça da conta de maquinismos, serão em todos os anos creditados $5 \%$, pelo menos, do seu custo, na conta de de- 
terioração de máquinas, devendo a respectiva importância ser debitada à conta de lucros e perdas, e que o art. 11 estabelece que dos lucros líquidos se retirem, pelo menos, $5 \%$ para fundo de reserva, tendo os restantes lucros a aplicação que a assembleia geral determinar; - que assim foram legais as deliberações pelas quais os lucros, foram aplicados, tanto à constituição do fundo de reserva legal, como à amortização da conta de maquinismos, como $a$ um mais profícuo aproveitamento da actividade industrial e que a distinção feita pelo usufrutuário não tem fundamento jurídico, porque todas as respectivas importâncias são produtos d'a actividade social, constituem "fundos" criados pela necessidade de assegurar a existencia e o desenvolvimento da sociedade, designadamente colocando-a em estado de se proder defender contra inevitáveis desgastes e contra as incertezas e contingências do futuro e de poder ir actualizando e melhorando os seus meios de produção, pelo que todas seguem a mesma trajetória, indo desde logo engrossar o activo social, no qual ficaram como que encorporadas; - que, porisso, não tem direito a elas o usufrutuário, que só o tem às rendas ou interesses provenientes da quota usufruida e só o são os lucros líquidos que a assembleia geral fez distribuir de harminia com o estipulado no pacto social; - que não se diga que essa encorporação se traduz em puro detrimento do usufrutuário, pois este deve gozar a causa usufruida como o faria um proprietário prudente, nos termos do art. 2223 do Cód. Civ., e certo é que a sociedade, para se manter, tem de melhorar continuamente os seus meios e processos de trabalho, e de ocorrer às necessidades, que o progresso, com as suas exigências sempre crescentes, lhe impõe, de contrário na luta de concorrência, em que se vê envolvida com as suas congéneres, baqueia e perde-se; - e, finalmente, que esses melhoramentos, que são condições necessárias da sua conservação e que realiza aplicando os fundos para isso destinados, além de manterem a sua laboração, ainda contribuem, como diz o próprio usufrutuário, para aumentar 
os rendimentos da sua actividade industrial e, portanto, os dividendos que ao usufrutuário pertencem enquanto dura o usufruto.

Quizemos referir o próprio caso, sobre que foi proferido o Ac., para salientar, não só a importância, que, em numerário, pode ter a solução do problema, mas também a ilegalidade e injustiça da que o Ac. lhe deu.

Conhecidos os seus fundamentos, apreciemo-los à face da lei portuguesa.

Em primeiro lugar, há a notar que o Ac. não fez a imprescindível distinção entre os fundos de amortização as reservas e ainda as aquisições tendentes a desenvolvei a actividade social.

Pior ainda - confundiu os "fundos" e as "reservas", quando são coisas totalmente diferentes.

Em segundo lugar, o Ac. baseia-se no art. 2.202 do Cód. Civ. e no art. 495 n. ${ }^{\circ} 3$ do mesmo Cód. para decidir que o usufrutuário só tem direito às rendas e interesses da cousa usufruida, quanido é certo que, pelo art. 2.206, o usufrutuário tem támbém o direito de gozar das coisas acrescidas, das servidões e, geralmente, de todos os direitos inerentes à cousa usufruida.

Em $3 .^{\circ}$ lugar, atendeu apenas ao regime legal das sociedades, constante das normas da lei e do pacto social, e não atendeu ao regime legal do usufruto.

$\mathrm{E}$, a propósito, vem o renovar aqui a crítica feita à maioria das soluções anteriormente expostas: - não se trata de questões a decidir entre o usufrutuário, ou o proprietário, e a sociedade, mas sim entre eles dois.

A sociedade pode, dentro da lei e do pacto social, tomar as deliberações que entender quanto à aplicação dos lucros; mas o usufrutuário tem direito, em relação ao proprietário, de obter dele as compensações devidas quando essas deliberações ofendem os seus legitimos interesses, dando lugar a que o proprietário se locuplete à sua custa.

A actividade da sociedade não pode ser limitada pelo respeito dos interesses do usufrutuário, mas se dela re- 
sulta a ofensa desses interesses em proveito do proprietário, cabe a este a obrigação de indenizar aquele de harmonia com o regime legal do usufruto, isto é, das disposições que regulam as relações entre ambos.

O próprio Ac. mostra isto mesmo, pois que, tendo a acção sido intentada contra a sociedade, foi chamado o usufrutuário para discutir com o proprietário a quem pertenciam os dividendos a distribuir.

Em $4 .^{\circ}$ lugar, o Ac. esqueceu ou desprezou importantes. normas legais reguladoras do usufruto.

Dizendo o Ac. que o usufrutuário deve gozar da cousa usufruida como um proprietário prudente, como lho ordena o art. 2223 do Cód. ICiv., parece querer indicar que é sobre ele apenas que recai o encargo de fazer as reservas e de suportar os prejuizos, que, por depreciação de valor, sofra a cousa usufruida.

Mas a dedução é errónea, porque não tem em conta outras disposições legais.

Nos termos do art. 2228, é ao usufrutuário que compete fazer as reparações ordinárias, isto é, as que, no ano em que fôrem necessárias, não excedam dois terços do rendimento liquido desse ano; e pelo art. 2229 é ao proprietário que incumbe fazer as reparações extraordinárias; e, se as não fizer, poderá o usufrutuário fazê-las à sua custa, se elas forem de utilidade real, exigindo o pagamento do valor que tiverem no fim do usufruto.

Portanto, as depreciações do activo, quer no balanço apareçam feitas directamente nos respectivos bens, que figurem no activo, quer apareçam feitas indirectamente pela constituição de fundos a inscrever no passivo, são suportadas pelo usufrutuário, pois que delas resulta que o dividendo (não os lucros) é menor.

Quanto a benfeitorias, e como tais se devem considerar as reservas estatutárias e livres e todas as aquisições e construções que aumentem o activo social, não é: ao usufrutuário que compete fazê-las. $\mathrm{E}$ como a socic. 
dade as faz com os lucros, que não são distribuidos, pertencem ao usufrutuário.

A lei não diz que só pertencem ao usufrutuário os lucros, que a sociedade atribuir à acção, ou quota, mas sim os interesses, que elas produzirem. $\mathrm{E}$ esses interesses são todos e não apenas os que a assembleia $d\lrcorner$ s sócios deliberar distribuir.

Além disso - convém repetir - ao usufrutuário pertence também a fruição das cousas usufruidas e de todos os direitos a elas inerentes, como prescreve o art. 2206.

O Ac., falando em "melhoramentos, que são condições necessárias da conservação da causa", confunde benfeitorias com reparações, que a lei nítidamente separa, estabelecendo regimes diferentes para umas e outras (conf. art. 495 e 499); dedicou-se a fazer uma retórica fácil em lugar de se ater aos princípios e normas legais.

Pela decisão do Ac., o proprietário locupletou-se com melhoramentos feitos à custa do usufrutuário — o que não é, nem legal, nem justo.

11 Tem o usufrutuário, além do direito de receber a parte correspondente dos dividendos, que, por fôrça da deliberação da assembleia da sociedade, fôrem distribuidos, o de receber quaisquer outras quantias, eventualmente distribuidas pelos sócios, ou capitalizadas, que sejam representativas de lucros.

Sendo o direito ao dividendo condicionado pela aprovação do balanço, o usufrutuário só tem direito a receber da sociedade a título de dividendo, a parte correspondenie aos lucros, cuja divisão pelos sócios a assembleia tenha deliberado, mas, por sua vez, na aprovação do balanço e especialmente na divisão dos lucros, a assembleia tem de conformar-se com as disposições da lei e do pacto social.

Nas suas deliberações, a assembleia deve avaliar os bens, que constituem o activo da sociedade, e, a não ser em casos especiais, em que a lei estabeleça regras para essa ava- 
liação, depende ela do puro arbítrio da assembleia; como ๑ usufrutuário pode intervir na respectiva reunião, discutindo e votando, nela defenderá os seus direitos e pugnará preceitos da técnica contabilistica e correspondendo à realidade, e por que se não criem fundos de amortização (58), ou se não aumentem os já criados por forma a que indevidamente se cerceiam os dividendos; se o não conseguir, como não poderá invocar ofensa de disposições expressas na lei ou no pacto social, não poderá requerer judicialmente a anulação das respectivas deliberações (cfr. Cód. Com., art. 146) ; mas, quando a sociedade se liquidar, ou no fim do usufruto, ele ou os seus herdeiros têm o direito de exigir do proprietário a respectiva compensação, com o fundamento nas disposições legais reguladoras do usufruto, e, ex-abundantis no princípio do não-locupletamento à custa alheia, nos países, em que a lei, ou em que a doutrina e a jurisprudência, como em Portugal, o consideram de aplicação geral e não apenas de aplicar nos casos especificados na lei (59).

Quanto à constituição de reservas (60), há ainda, em 1. lugar, que atender às disposições da lei e do pacto social.

Todas as sociedades anónimas e por quotas têm de constituir a chamada reserva legal (Cód. Com., art. 191; Lei de

58. Consideramos aqui fundos de amortização ou de depreciação as quantias que são inscritas no passivo para compensar as desvalorizações que normalmente vão sofrendo certos valores do activo; em lugar de se diminuir no activo o valor desses bens, criam-se no passivo esses fundos. 0 resultado é o mesmo.

59. Guilherme Moreira, Inst. de dir. civ., vol 1.., pág. 621; Cunha Gonçalves, Trat. de dir. civ. vol. 4.․, pág. 731; Gaz. da Rel. de Lisboa, t. 46, pág. 9; Acs. do Sup. Trib. de Just. de 14 junho de 1935 e de 2 de junho de 1940, na Gaz. da Rel. de Lisboa, t. 49, pág. 198, e t. 54, pág. 190 ; etc.

60. Consideramos aqui reservas - as quantias, que são inscritas no passivo para compensação de futuros prejuizos ou depreciações eventuais. 
11 de Abril de 1901, art. 34); mas a algumas sociedades de natureza especial, como as de seguros, impõe a lei outras reservas; aquela e estas, embora aumentem o activo soci it com o fim de ocorrer a eventuais necessidades futuras, pelo que o usufrutuário poderá ainda aproveitar-se delas, se o usufruto durar alguns anos, são constituidas com os lucros que deixaram de ser distribuidos pelos sócios, de forma que o usuffutuário, ou os seus herdeiros, têm o direito de, no fim do usufruto, ou quando se proceda à liquidação da sociedade, exigir do proprietário a respectiva compensação.

Além das reservas legais, pode haver, e há, frequentemente, reservas impostas ou permitidas no pacto social, geralmente denominadas estatutárias, em referência aos estatutos das sociedades anónimas; e quanto a elas, quando o pacto social seja anterior à constituição do usufruto, deve aplicar-se a doutrina que acabamos de formular quanto às reservas legais.

Depois da constituição do usufruto, podem, em alteração do pacto social, feita em conformidade com a lei, ser impostas novas reservas; nas assembleias, em que seja de. liberada essa reforma e a criação dessas reservas, pode $o$ usufrutuário pugnar pela defesa dos seus direitos; mas, se não conseguir evitar essas reservas novas, ele ou os seus herdeiros têm o direito de, no fim do usufruto, ou quando a sociedade liquide, exigir do proprietário a respectivé compensação.

Se a assembleia geral deliberar criar uma nova reserva, que não seja imposta nem pela lei, nem pelo pacto social, entendemos, com Venezian, que o usufrutuário pode, como qualquer sócio, requerer judicialmente a anulação da respectiva deliberação com fundamento na violação das disposições da lei e do pacto social, que traçam os limites dentro dos quais a assembleia geral pode mover-se pelo que respeita à distribuição dos lucros líquidos. 
Em regra, no pacto social determina-se a aplicação que devem ter os lucros, ou dão-se à assembleia poderes, mais ou menos latos, para fazer essa aplicação.

Sempre que a assembleia geral of enda tais disposições do pacto social, o usufrutuário tem o direito de requerer a anulação e a suspensão das respectivas deliberações, nos termos dos art. 146 e 186 do Cód. Com.

Quando, porém, o pacto social contenha cláusulas tão latas que permitam à assembleia geral fazer aquisições, que aumentem o activo social, o usufrutuário ou os seus herdeiros têm, no fim do usufruto, ou quando da liquidação da sociedade, o direito de compensação, a que já nos temos referido.

Como a compensação só pode ser exigida do proprietário, é óbvio que só no fim do usufruto, ou quando se proceder à liquidação da sociedade, pode ser exigida, pois ele não pode ser obrigado a dar uma compensação de valores, que ainda não recebeu.

Daqui resulta uma maior dificuldade na prova dos fundamentos de facto, por que deve ser pedida a compensação e pode resultar que esta não seja completa - quando o usufrutuário não tenha podido suprir a falta do que devia receber e não recebeu.

Quere dizer - o não ter recebido, na altura própria, o que lhe competia pode causar ao usufrutuário um transtorno de que não poderá depois ter compensação bastante.

Mas esses inconvenientes não podem evitar-se.

Na compensação haverá que ter em conta as considerações feitas relativamente a reparações ordinárias e extraordinárias e a benfeitorias e também o aproveitamento que o usufrutuário ainda possa ter tirado, durante a vigência do usufruto, das reservas e outras aplicações que tenham sido dadas aos lucros.

Resta-nos fazer uma ressalva importante em relação aos casos em que a assembleia dos sócios proceda a desva- 
lorização e crie ou aumente fundos de amortização ou de reservas, cuja criação o pacto social permita.

Tôdas estas faculdades são atribuidas à assembleia tendo em atenção os interesses da sociedade e para que possam ser acautelados e defendidos.

Se, porém, as deliberações que, no uso dessas faculdades, forem tomadas, tiverem por fim servir, não o interesse social, mas o interesse de alguns sócios, ou prejudicar os interesses de uns em benefício de outros, são ínquinadas de vício, que as torna nulas.

Bem pode supor-se, por exemplo, que uma oliarquia de sócios ricos, dominando na assembleia, aumente as amortizações e crie ou aumente os fundos e as reservas, prejudicando ou diminuindo a distribuição do dividendo, com o fim de produzir a baixa na cotação das acções, ou a desvalorização das quotas, e de conseguir a sua aquisição por baixo preço, lesando altamente os outros sócios.

Haverá então um abuso de direito.

$E$ nos paises em que, como em Portugal (61), a doutrina e a jurisprudencia admitem a chamada teoria do abuso de direito, podem os sócios, e, no caso, o usufrutuário, requerer a anulação das deliberações, que estejam inquinadas desse vício (62).

12 O problema relativo ao direito de opção, de preferência, na subscrição de novas acções tem sido solucionado por algumas legislações, como a brasileira e a italiana.

O já cit. dec.-lei brasileiro $n .^{\circ} 2627$, dispõe, no $\S 4 .^{\circ}$ do seu art. 11, que esse direito, se não fôr exercido pelo "accionista", poderá sê-lo pelo usufrutuário.

$\mathrm{O}$ art. 2352 do Cód. italiano confere-o ao "sócio" (proprietário), acrescentando que, se ele não fizér o pagamento da quantia devida pelo menos três dias antes do respectivo

61. Tito Arantes, Do abuso do direito; Gaz. da Rel. de Lishoa. t. 54, pág. 219, nota; etc. 
vencimento, o seu direito será vendido, por sua conta, por intermédio de um agente de câmbio, ou de um instituto de crédito.

A doutrina do decreto brasileiro é muito simples, mas nem é conforme ao regime legal do usufruto, nem tem em devida conta os legítimos interesses do proprietário e do usufrutuário.

No entanto, a conceder o direito de opção só ao proprietário, deve, ao menos, seguir-se, contra a opinião de alguns autores (63), a solução que o dec. brasileiro dá de o conceder ao usufrutuário quando o proprietário não o queira exercer.

$\mathrm{E}$, ainda à face do dec. brasileiro, parece-nos que o proprietário poderá ceder o seu direito, e só se o não exercer, ou não ceder, é que ele pertence ao usufrutuário.

Essa cessão pode representar um valor importante, quando, como frequentemente acontece, as acções são emitidas ao par, isto é, pelo seu valor nominal, sendo maior o valor real das acções antigas quando a nova emissão se realiza.

A'disposição do art. 2352 do Cód. Civ. italiano não está redigida com clareza, tendo dado lugar a interpretações divergentes.

Geralmente, tem sido interpretada como concedendo apenas ao proprietário o direito de opção, acrescentando um ou outro autor que é concedido em compensação de ser concedido ao usufrutuário o direito de voto (65).

63. Segundo Charpentier, cit. por Houpin et Bosvieux (obr. e vol. cit. pág. 583), a criação de reservas será legítima se a assem. bleía proceder de acordo com o interesse colectivo, sem abusar do seu direito.

64. Vide o n.o 11.

65. Messineo, Manuale di dir. civ. e com., vol. $2 .^{\circ}$ pág. 157; GASPERONI, Le azioni de società, pág. 201; LoRDi, ob. e vol. cit., pág. 283; Sent. do Tribunal de Roma de 12 de Abril de 1943, na Riv. de dir. com., 1944, 2.॰., pág. 128. 
Mas Alberto Asquini (66) discorda desta interpretação, sustentando que, sendo o direito de opção geralmente concedido para compensar os antigos sócios da depreciação que as antigas acções sofrem com a emissão de acções novas quando o preço da emissão é inferior ao valor efectivo das acções antigas, ele pertence ao proprietário e ao usufrutuário; - o art. 2.352 apenas regula o modo de exercício do direito de opção; a sua disponibilidade compete ao accionista nu-proprietário, que tem a disponibilidade da acção e que, entendendo subscrever as novas acções, deverả pagar a respectiva importância até três dias antes do vencimento; se o não fizer, é vendido o seu direito de subscrição, por sua conta, por intermédio de um agente de câmbio ou de um instituto de crédito; realizando-se esta vendia, o usufrutuário tem, por aplicação de regime legal do usufruto, direito a que este passe para o produto da cessão; se o proprietário subscrever as novas acções, o usúfruto só pode recair sobre uma quota de cada acção nova, correspondente à desvalorização que sofrem as as acções em favor das novas, a qual será aproximadamente igual ao valor que no mercado tenha obtido o direito de subscrição; quando não haja esse mercado, como quando as respectivas acções não estão cotadas na bolsa, esse valor deverá ser fixado por avaliação, a menos que o proprietário chegue a um acôrdo, que pode ser, por exemplo, o de dividirem as novas acções numa determinada proporção.

A construção é engenhosa, cabe dentro da letra do art. 2352 e está de harmonia com o regime legal de usufruto, atendendo tanto aos legítimos interesses do proprietário como do usufrutuário, pelo que merece aceitação, mesmo nos países em cuja legislação não haja norma legal correspondente à do cit. art. do Cód. italiano.

Mas a última parte, porque é muito complicada, poderá com vantagem ser substituida pela solução preconizada

66. Ob. e lug. cit., pág. 30 . 
por Garrigues (67) : - na falta de acordo, pagar a usufruđuário (anualmente, acrescentamos nós) ao proprietário o juro do capital empregado na aquisição das novas acções.

Idêntica a esta solução, mas insuficiente, é a apresentada por Chambaz-Leblond (68), que nos diz o seguinte: - "Le droit de souscription n'est pas un fruit de l'action, car il lui manque le caractère essentiel du fruit, à savoir la periodicité; c'est un accessoire du capital que appartient por voie d'accroissement au nu-propriétaire, mais qui reste soumis à la jouissance de l'usufruitier. En cas de vente de ce droit, l'usufruitier peut prétendre aux revenus du prix; si le droit est utilisé, actions nouvelles sont gravées d'usufruit".

Chambaz-Lebrond não diz expressamente a quem cabe escolher entre a subscrição ou a cessão do respectivo direito, mas depreende-se que é ao proprietário; a última afirmação é que não é suficientemente clara. Dizendo que o pagamento das novas acções é um encargo das acções oneradas com o usufruto, não diz em que proporção o encargo deve ser suportado pelo proprietário e pelo usufrutuário e é este ponto mais difícil de resolver.

Sanches Torrez (69) faz longas considerações jurídicas e extra-jurídicas para chegar à conclusão de que em. todos os casos (emissão ao par, abaixo do par para o subscritor, ou com prêmio para este) a preferência na subscrição deve caber ao nu-proprietário, mas, se este o não exercer, pode o usufrutuário exercê-lo; num e noutro caso não há lugar a qualquer compensação de um para com outro.

Quanto à cessão do direito de subscrição, sustenta que só cabe ao proprietário, sem que o usufrutuário tenha qualquer direito sobre o preço da cessão.

67. Tratado de derecho mercantil, 1-2, n. 346.

68. Précis des sociétés, pág. 453.

69. Obr. e vol. cit. 
Todas estas soluções nos parecem menos respeitadoras: do regime legal do usufruto e nada equitativas.

13 Quando o aumento de capital seja mediante a distribuição gratuita de novas acções em proporção das antigas, há, quanto a nós, lugar a fazer uma distinção importante: - se as novas acções representam apenas lucros acumulados, que constituem reservas, ou representam uma distribuição de dividendos disfarçados, devem pertencer ao usufrutuário, que tem direito a todos os frutos, que a cousa usufruida produzir; - se representam apenas valorização do activo resultante de várias circunstâncias de ordem econômica, como as que respeitam à valorização da moeda, de certas mercadorias, ou da propriedade imóvel, então as novas acções, correspondentes às antigas oneradas. de usufruto, oneradas ficam também.

Haverá, no entanto, que atender, nos dois primeiros casos, à data da constituição do usufruto, tendo o usufrutuário direito apenas às acções correspondentes às reservas. constituidas posteriormente.

Garrigues (70) dá as mesmas soluções, mas limita primeira a representarem as novas acções reservas livres, e informa que da jurisprudência do Supremo Tribunal de Espanha se deduz: - $10^{\circ}$ que os benefícios obtidos pelas acções são produtos, confirmando-se neste ponto a qualificação de frutos industriais; - $2^{\circ}$ que esses benefícios obtidos por causa das antigas acções não podem considerarse como acessão delas, que corresponda à sua propriedade; - $3^{\circ}$. que a complexidade do usufruto de acções não autoriza o intérprete a contrapor simplesmente o direito ao dividendo e os demais direitos de fruição derivados da posse das acçóes, limitando àquele o conteúdo normal do usufruto; o usufrutuário tem direito, não só ao dividendo.

70. Obr. e vol. cit., pág. 777. 
mas também a tudo o que, sob qualquer outra forma, represente um fruto.

Segundo o critério do Supremo Tribunal, pertence ao. usufrutuário tudo o que a sociedade distribua "em forma" de dividendo, e "por via" de dividendo".

Todavia Garrigues informa ainda que num aresto mais recente, o Supremo Tribunal considera como frutos e, portanto, como cabendo ao usufrutuário, as novas acções, quer o aumento de capital se faça com reservas, quer com entrada de numerário nos cofres da sociedade.

Pelo que dissemos no . $^{\circ}$ anterior, se vê que, com GarRIGUES, discordamos da doutrina do aresto, quanto a este ultimo caso.

O art. 2442 do Cód. Civ. italiano supõe o aumento de capital com a parte disponivel das reservas e fundos especiais inscritos no balanço ou por meio de novas acções, ou mediante aumento de valor nominal das acções em circulação. No $10^{\circ}$ caso, acrescenta, as acções da nova emissão devem ter as mesmas caracteristicas das que estão em circulação e devem ser distribuidas gratuitamente e proporcionalmente pelos accionistas.

Alberto Asquini (71) observa que o aumento de capitaI mediante a utilização de reservas pode ser considerado como uma distribuição extraordinária de lucros - e tal é o ponto de vista do Fisco italiano - e, então, em tal ordem de ideias, poder-se-ia ser tentado a sustentar que, na medida em que se utilizam para operação reservas provenientes dos lucros obtidos durante o periodo do usu fruto, a valorização das acções ou as acções gratuitas da nova emissão devem pertencer em plena propriedade ao usufrutuário; mas, afinal, acha esta tése excessiva, pois abrangeria os aumentos de capital derivados de simples valorização monetária, que são os mais frequentes actual-mente.

(1. Luğ. cit., signanter pág. 27. 
O que para Alberto Asquini é óbvio é que pertence ao nusuîrutuárioo gozo dos novos títulos distribuidos gratuitamente ou das antigas acções valorizadas.

Mas a tese mais equitativa e mais em harmonia com as normas reguladoras do usufruto é a que defendemos, e que deve ser adoptada, quando a lei não dê expressamente outra solução ao problema.

A aplicação da que apresentamos atende à diferença que há entre os dois casos - em que o aumento do capital depende da utilização das reservas, ou da valorização de verbas do activo.

Quando o aumento resulte ao mesmo tempo daquela utilização e desta valorização, pode havir dificuldade em a aplicar, mas essa dificuldade não deve ser motivo para a pôr de parte e substituir por uma solução menos boa.

14 Se quando se constitue o usufruto, as acções ainda não estão integralmente pagas, a quem compete realizar o pragamento das prestações vincendas?

Prevalece a opinião de que compete ao proprietário (Planiol, Garrigtess, Sanchez Torres, etc.), mas Venezian entende que cabe ao usufrutuário.

A nós, parece-nos manifesto que não pode ser, nem só ao proprietário, nem só ao usufrutuário, porque ambos aproveitam com a integralização do capital.

A obrigação deve competir a ambos; mas em que termos?

O art. 2352 do Cód. Civ. italiano de 1942 solucionou também este problema, preceituando que deve o usufrutuário fazer o pagamento com direito a restituição no fim do usufruto.

Não nos parece boa a solução; importa um encargo para o usufrutuário, sem a devida compensação, visto que aquela restituição não é com juros (72).

72. AsquinI, ob. e vol. cit., pág. 36 . 
Alberto Asquini, que a julga conforme aos princípios, supõe a hipótese de o usufrutuário não fazer o pagamento e entende que, aplicando-se, por analogia, o preceito do art. 1010 daquele Cód., pode o proprietário fazer o pagamento, debitando o usufrutuário pelos juros durante o usufruto, ou fazer vender a acção transferindo o usufruto para o produto.

Quanto a nós, a obrigação do pagamento deve caber ao proprietário, com o direito a receber anualmente do usufrutuário os juros da respectiva quantia. Ao usufrutuário, o direito de receber os dividendos, quando os houver.

Se, porém, o proprietário não fizer o pagamento, deve podier fazê-lo o usufrutuário, ficando êle ou os seus herdeiros com o direito a receber do proprietário a respectiva importância, com juros no fim do usufruto.

A este $2^{\circ}$. caso também poderá dar-se outra solução análoga à dada pelo $\S 2^{\circ}$ do art. 170 do Cód. Com. no caso de um subscritor primitivo ser obrigado a realizar algum pagamento por conta de uma acção de que já não seja proprietário: - fazendo o usufrutuário o pagamento, a acção ficaria sujeita ao usufruto apenas na proporção correspondente làs partes do capital pago antes e ficaria pertencendo em plena propriedade ao usufrutuário na parte correspondente ao capital por êle desembolsado.

Mas a primeira solução parece-nos mais simples.

Se nenhum deles efectuar o pagamento e se a acção, nos termos da lei ou do pacto social, fôr vendida pela sociedade, o produto de venda ficará pertencendo a ambos, respectivamente em nua-propriedade e em usufruto.

Se d'a falta de pagamento por ambos resultar para a sociedade o direito a qualquer indemnização, por ela devem ambos ser responsáveis solidàriamente.

$\mathrm{O}$ que acabamos de dizer aplica-se ao caso de, nas sociedades por quotas, estas não serem logo integralizadas. Quando a sociedade delibere dar por liberadas as ações, completando com reservas o que falta para integralizar o 
capital, tem o usufrutuário direito a ser compensado pelo proprietário.

15 Ainda segundo a lei portuguesa das sociedades por quotas, assim como segundo algumas outras legislações, no pacto social dessas sociedades pode estabelecer-se a obrigação para os sócios de entrar com prestações suplementares além das necessárias para pagamento integral das quotas respectivas (Lei de $\mathbf{1 1}$ de Abril de 1901, art. 17).

Duma maneira geral, deve aplicar-se a esse caso o que ficou dito quanto à falta de pagamento de prestações tendentes a integralizar o capital; há, todavia, que ter em conta o disposto no art. 18 da cit. Lei, segundo o qual, se a obrigação de efectuar prestações suplementares não fôr restrita a uma quantia determinada, pode o sócio exonerarse dessas prestações pondo a sua quota à disposição da sociedade.

Este direito de saída por qual deles pode ser exercido? Pelo proprietário, ou pelo usufrutuário?

Entendemos que qualquer deles o pode exercer; todavia, se for exercido pelo proprietário, pederá o usufrutuário satisfazer a prestação em divida, ficando com a propriedade plena de respectiva importância; se fôr exercido pelo usufrutuário e a prestação for paga pelo proprietário, ficarlhe-á a respectiva importância pertencendo em plena propriedade.

16 Soluções análogas se devem tomar nos outros casos, em que seja conferido ao sócio o direito de saída.

Alberto Asøuini (73) entende que, importando o uso de tal direito um acto de disposição, só o proprietário tem esse direito, ficando ao usufrutuário o direito de fazer

73. Ob. e lug. cit., signanter, pág. 25 . 
transferir o usufruto para a importância que resultar da liquidação da quota ou parte social.

Mas o proprietário, exercendo o direito de salída, não dispõe apenas da propriedade, dispõe também do usufruto; e não o pode fazer sem o consentimento do usufrutuário; este é que pode dispôr do usufruto (Cód. Civ. art. 2207) e essa disposição abrange manifestamente a transferência do usufruto de uma cousa para a outra.

17 Quanto ao direito, que a sociedade possa ter, de excluir um sócio, os casos em que ele pode ter lugar variarão muito consoante as respectivas disposições da lei e do pacto social.

Sendo a lei omissa, haverá que atender à especialidade de cada caso para lhe dar a solução conveniente. Apenas, de uma maneira geral, se poderá dizer que, em regra, a exclusão abrangerả tanto o proprietário como o usufrutuária; mas, se apenas for motivada por facto de um deles, o outro terá o direito de ser indenizado pelo que deu causa à exclusão.

18 Dissolvida a sociedade, há lugar à sua liquidaçãn e nesta, pagos os débitos, o saldo deve ser repartido pelos sócios na proporção da parte que lhes for devida (Cód. Com., art. 138).

Mas o que corresponda a uma parte social, a uma quota, ou a uma acção em usufruto, pertence ao nu-proprietário, ou ao usufrutuário, ou a ambos?

Como o art. 2241 do Cód. Civ. diz que o usufruto acaba pela perda total da cousa usufruida, salvo no caso previsto no $\S 10^{\circ}$ do art. 2246 (usufruto do edifício para cujo seguro o usufrutuário tenha concorrido), parecerá, ¿̀ primeira vista, que, dissolvida a sociedade, se perdeu a cousa usufruida - a parte, quota social, ou acção - e se extinguiu o usufruto. 
Mas não é assim. A cousa não se perdeu totalmente, a não ser que na liquidação nada ficasse para distribuir pelos sócios.

Se alguma cousa ficar, para ela se transfere o usufruto, e, sendo assim, a parte correspondente desse saldo deve pertencer ao nu-proprietário e ao usufrutário.

Isto, em regra. Podem, porém, supor-se, como supõe Alberto Asquini, estas três hipóteses: a) a quota de repartição de saldo é quasi igual ou inferior ao valor nominal da parte ou da quota social, ou da acção; neste caso, a regra é aplicada sem lugar a dúvida; $b$ ) essa quota é superior ao valor nominal por efeito de valorização do activo; neste caso, também a regra é aplicável; c) a superioridade resulta de reservas acumuladas ou de bens adquiridos com lucros; neste caso, esse escritor italiano sustenta que a mesma regra se deve aplicar, porque os lucros foram capitalizados por deliberações da sociedade e, portanto, o usufrutuário não tem direito ao aumento do valor resultante dessa capitalização.

Discordamos da solução dada a esta $3{ }^{a}$ hipótese, não obstante ser também apresentada por outros autores italianos (75), pelas razões atrás aduzidas quando tratámos pròpriamente do problema das reservas (ns..$^{\circ} 10$ e 11)

23 Há ainda um problema melindroso, relativo ao usufruto de partes sociais, que nem por ser de grande raridade deve ficar no olvido.

Referimo-nos ao que resulta da responsabilidade ilimitada e solidária, mas subsidiária, dos sócios de sociedades em nome colectivo.

Como é sabido, há vários sistemas legislativos quanto ao momento e à forma de efectivar essa responsabilidade,

74. Ob. e vol. cit., pág. 22.

75. Venezian, ob. cit., vol. 2.0, pág. 57; Messineo, T'itoli di credito, vol. 2.0., pág 285; Gasperoni, ob. cit., pág. 201. 
A legislação portuguesa adoptou o sistema latino, estabelecendo que é preciso que o capital da sociedade seja excutido, isto é, que a sociedade já não tenha bens, para. que os sócios respondam pelas obrigações sociais.

A determinação de quando é que se pode considerar excutido o capital social é um problema de solução fácil,. que o art. 825 do Cód. de proc. Civ. veiu complicar (76); mas aqui o que nos interessa saber é a quem cabe essa responsabilidade para com os credores, excutido o capital. social.

Não é na legislação sobre sociedades, que podemos encontrar a solução, mas sim, talvez, na reguladora do usufruto.

Dizemos talvez, porque na legislação portuguesa não a encontramos.

Não nos parece que seja de invocar, nem o art. 2228 , que trata das reparações ordinárias indispensáveis para a. conservação da cousa usufruida, nem o art. 2229, que trata das reparações extraordinárias, nem o art. 2234 que regúla a hipótese de sobre a cousa hipotecada recair uma hipoteca.

Tão pouco será de considerar que a exigência dessa: responsabilidade dos sócios resulta da dissolução da sociedade, porque embora seja feita essa exigência e seja satisfeita, a sociedade pode continuar.

Mas, do disposto no art, 2206, segundo o qual o ,usufrutuário tem o direito de gozar de todos os direitos inerentes à cousa usufruida" se poderá e deverá deduzir que também deve participar de todas as obrigações a ela inerentes, ressalvadas aquelas que por lei, especialmente e in totum, competem ou só a ele, ou só ao proprietário. (confr. arts. 2238 e 2239).

76. Veja-se o nosso artigo - A responsabilidade dos sócios pelas obrigações sociais e o art. 825 do Cód. do Proc. Civ.. na' Gazeta da Relação de Lisboa, t. 54, pág. 65. 
Assim sendo, essa responsabilidade deve recaír sobre ambos e, sem dúvida, solidàriamente em relação aos respectivos credores.

O que é duvidoso é a medida em que, nas relações entre si, cada um deve participar dessa responsabilidade.

Encontramos ainda na lei a solução do problema.

Para efeitos juridicos (não fiscais), o usufruto vitalicio tem, em relação à sua nua-propriedade, um valor, mais ou menos determinado: - o art. $607 \mathrm{n}^{\circ} .5$ do Cód. do Proc. Civ. dispõe que o valor do usufruto se obtém multiplicando por 10 o rendimento anual, podendo, porém, o produto ser aumentado ou diminuido, conforme a duração provável do respectivo direito.

Se o usufrutuário é novo, de meia edade, ou de edade avançada, assim o usufruto poderá, com maior ou menor probabilidade, durar mais ou menos; o aumento, ou dimınuição daquele produto, quando não fôr determinado por acôrdo, poderá e deverá sê-lo utilizando-se as tábuas de que se servem as companhias de seguros para determinar as rendas vitalícias.

Se o usufruto é temporário, o que é muito menos frequente, o produto será aumentado ou diminuido consoante a duração do usufruto.

Desta solução, que apresentamos, duas deduções há a fazer: - a) que os credores têm maior garantia; em lugar de um só têm dois patrimónios a responder pelos respectivos débitos; - b) que, declarada a falência da sociedade, deve nos termos do art. 1324 do Cód. de Proc. Civ., ser declarada também a falência tanto do proprietário como do usufrutuário.

24 Cremos ter versado, não todos, mas, ao menos, os mais importantes e fundamentais problemas suscitados pela constituição do usufruto em acções, partes ou quotas sociais. 
Os que ficaram sem referência especial poderão ser solucionados utilizando o princípio directivo acima indicado e atendendo, nem apenas ao regime legal sobre sociedades, nem apenas ao regime legal sobre usufruto, mas atendendo, em justa medida, a um e outro, de forma a que os direitos e obrigacões de cada um dos titulares dos direitos da nuapropriedade e do usufruto sejam equitativamente distribuidos. 